Celestinesca 3I (2007): 133-164 https://doi.org/10.7203/Celestinesca.31.20074

\title{
Richard Strauss, Stefan Zweig, Joseph Gregor and the Story of the Celestina Opera that Almost was, with a Bibliographical Appendix of Celestina Operas in the Twentieth Century
}

\author{
Joseph T. Snow \\ Michigan State University \\ \& \\ Arno Gimber \\ Universidad Complutense-Madrid
}

[This modest study narrates the little-known history of a Strauss opera that "almost» happened. It had its genesis when, while working on another project, I ran across a reference to Celestina that surfaced in an exchange of letters between Stefan Zweig and Richard Strauss. When I fi nally located an English translation of the original letters - from 1935 the reference turned out to be much more than the casual mention of the revered Spanish masterpiece $(1499,1502)$ I'd anticipated; it consisted of an active exchange of letters that discussed (and confirmed) the operatic potential of the work and particularly of its central character, the exuberant go-between, Celestina. From this initial series of hints, the scope of the topic grew wider when the Austrian theater historian, Joseph Gregor entered the picture (1935-1936). To help me assemble and make available some of the German-language sources for the following account of the contemplated Strauss opera based on Celestina - an early sixteenth-century Spanish classic work of great tragic potential-, I enlisted the expert collaboration of Arno Gimber, a specialist in germanística with a long-held interest in Celestina. The resulting study combines the interest and efforts of both. J. T. Snow] 


\section{Prologue}

Perhaps the most disconcerting aspect of the research into Richard Strauss' interest in writing a musical score for a contemplated opera based on Celestina was to find that, precisely because the project never materialized musically it practically disappears in Strauss scholarship. There does exist, however, a complete sketch for a three act opera drafted by Joseph Gregor, although the major biographical studies (life and works) of Strauss fail to take it into account despite its being discussed in available letters from March of 1935 through October of $1936 .{ }^{1}$ The reconstruction presented here is based, therefore, almost entirely upon two sets of letters, those that passed between Stefan Zweig, the original proponent of the idea for an opera based on Celestina, and Strauss, and those that passed later between Strauss and Joseph Gregor, a friend of Zweig's and a great admirer of Strauss. ${ }^{2}$ Prior to the time of these exchanges, we wish only to note that all three men had previously been drawn to and motivated by works of early Spanish theater and one objective for this research is, in large part, to remind literary and musical scholars alike of this shared interest.

\section{9-1935}

When Hugo von Hofmannsthal, Richard Strauss' habitual librettist from the time of their first collaboration (Elektra 1909), died in 1929, they were at work on Arabella, the opera of which Strauss completed the composing according to the plans Hofmannsthal had left for the final two acts. Arabella had its debut in Dresden on July 1, 1933, with Clemens Krauss conducting. Strauss (1864-1949), then sixty five and in the prime of his musical career, was casting about for a suitable successor to Hofmannsthal: he knew this would be a far from easy task as his respect for Hofmannsthal's abilities - after twenty years of collaboration - was

1.- These certainly include those of Walter Panofsky, Richard Strauss. Partitur eines Liebens (Munich: Piper, 1965); Otto Erhardt, Richard Strauss. Su vida y sus obras (Buenos Aires: Ricordi Americana, 1980); Rudolf Hartmann, Richard Strauss. Opéras de la création à nos jours (Fribourg: Office du Livre, 1980); Jean Clausse, Richard Strauss (translated from the French by M. P. Díaz González, Madrid: Espasa-Calpe, 1980²); Bryan Gilliam, The Life of Richard Strauss (Cambridge: UP, 1999); and the detailed article in The New Grove Dictionary of Music and Musicians, vol. 24, 2 ed. (London: Macmillan, 2002). An exception is Ernst Krause, Richard Strauss. Gestalt und Werk (Wiesbaden: Breitkopf \& Hartel, 1980), who does mention the project and cites from a few of the letters (p. 396).

2.- Both sets of letters are mentioned in the bibliography listed in vol. III, p. 1455 of E. H. Müller von Asow, Richard Strauss. Thematisches Verzeichnis (Munich: L. Doblinger, 1966). There, the original work, Tragicomedia de Calisto y Melibea, is attributed to Rodrigo Cota and Fernando de Roja [sic]. 
colossal. He would not have long to wait for such a successor. In 1931, when Anton Kippenberg, Stefan Zweig's editor, wrote to Strauss and suggested his client as a potential librettist, a new and powerful —albeit brief- collaboration was in the offing. At that first meeting with Zweig, which took place in Munich's Hotel «Vier Jahrezeiten» on November 20, 1931, Strauss was greatly impressed both with the man and his suggestions for musical possibilities. Their collaboration, in fact, began almost immediately and with genuine enthusiasm on both sides. Of the two ideas discussed at this meeting, Strauss seemed not so much interested in a danced pantomime that Zweig had been mulling over for some time, as he was immediately intrigued by the idea of an opera based on Ben Johnson's Epicoene (1609). A verbal contract was all that was ever needed and they both began work on what would become Die schweigsame Frau (The Silent Woman) in 1932. By January 31, 1933, when Adolf Hitler came to power, Strauss had almost finished the composition of Act I.

It was a particularly difficult moment for this newly forged team, for Zweig was a Jew and Hitler soon after prohibited the theatrical performance of all non-Arian works, even of works in which a Jew even had played a role in creating. Not easily intimidated, Strauss continued working on the opera with Zweig during 1934 and 1935. Strauss was not hindered in this as he was certainly Germany's greatest living composer and it was well known that Hitler enjoyed his music. Hitler had, additionally, approved Strauss' appointment as president of the Reichsmusikkammer. The polemic that ensued around the planned Dresden debut of this collaborative work of a German with a non-Arian was heatedly debated at the highest governmental levels, even to the point at which Hitler himself - having personally read through the entire three-act libretto to ensure its political orthodoxy - authorized, exceptionally, the debut of Die schweigsame Frau and then, along with Josef Goebbels, made plans to attend the opening night. ${ }^{3}$

When it became known to Strauss that the playbill was to state simply that the opera was adapted from a work by Ben Johnson, his insistence on Zweig's receiving full credit for his role as librettist was, however reluctantly, honored. In the event, a storm in Hamburg prevented Hitler and Goebbels' flight to Dresden for the opening of the opera. This took place on the evening of June 24, 1935, with Karl Böhm conducting. Strauss was there but Zweig, for obvious reasons, did not attend. However, the racism that resulted from the Jewish Zweig's blatantly proclaimed participation was, apparently, sufficiently polemical that the production was halted after only three performances. Further performances

3.- It is interesting to read Zweig's own account of his collaboration with Strauss in his El mundo de ayer. Memorias de un europeo (Barcelona: El Acantilado, 2001, pp. 463-474. The German original is titled, simply, Die Welt von Gestern (Stockholm: Bermann-Fischer, 1942). 
of Die schweigsame Frau were forbidden, not only in Dresden, but in all Germany. As a result, Strauss was «invited» to resign his post as president of the Reichsmusikkammer. He did so two weeks later, on July 6, 1935.

This unhappy episode could not sever the bond between Strauss and Zweig. Even though Goebbels forbade further collaborations with Zweig, Strauss' letters show clearly that he continued to urge his friend, now based in Austria, to collaborate with him on yet a second opera. Zweig, seeing the situation in which this would place Strauss, declined the offer to do so time and again, but he did offer the names of others he believed would serve Strauss well as possible substitute librettists (for the record they are: Rudolf Binding, Alexander Lernet-Holenia, Robert Faesi and Joseph Gregor). Strauss was, for varying reasons, opposed to them all. In Stefan Zweig, he believed he had found the perfect successor to Hugo von Hofmannsthal. It was to take all of Zweig's considerable powers of persuasion, and influence, to finally have Strauss accept Joseph Gregor. ${ }^{4}$ Indeed, the first meeting of Strauss and Gregor took place the day following Strauss' forced resignation from the Reichsmusikkammer, on July 7, 1935.

\section{March-October, 1935}

The terminus ab quo of the Zweig-Strauss Celestina project is a letter from Stefan Zweig to Richard Strauss written from the Hotel Regina in Vienna on March 14, 1935. Zweig, after acknowledging several matters discussed in a previous exchange of letters with the composer, introduces a new topic he believes would interest Strauss

... Meanwhile I am studying an old Spanish tragicomedy, Celestina, which for years I have been considering for an adaptation and which probably could provide the basic idea for an opera. It is the oldest drama of Spanish literature, older than the works by Calderón and Lope, and remarkable because it moves on two levels: two lovers, noble, romantic, in the lyrical tradition, patterned after Romeo and Juliet ${ }^{5}$; and the lower elements, crude, vulgar; in between, as mediator, the unique figure of $\mathrm{Ce}$ lestina, a full-blooded matchmaker with an outstanding

4.- Since we are here focused on Gregor and Strauss and their Celestina project, it might be useful to record that Strauss and Gregor did eventually collaborate on three operas: Friedenstag (Munich, July 24, 1938, Clemens Krauss conducting), Daphne (Dresden, October 15, 1938, Karl Böhm conducting), and Der Liebe der Danae (Salzburg, October 28, 1942, Clemens Krauss conducting).

5.- Zweig's point of view ("patterned after») is that of the twentieth century of course. Calisto and Melibea were created a century before Shakespeare's classic lovers. 
command of words, a female Falstaff, juicy, elementary. What is noble, lyrical, tender in the upper level shown is also with the servants, scoundrels, and scamps, as in a distorting mirror. This contrast seems to me a most appealing musical theme - to show love in its noble and crude forms, romanticism and crass realism mixed as in everyday life. Clearly such a work can never be translated, only adapted. There is an adaptation in verse in Zoozmann. ${ }^{6}$ Perhaps you could have it ordered from a library; I do not recall the title exactly, but any librarian will be able to find it from the title Celestina, freely rendered by Richard Zoozmann. The material could be interesting for you, I believe, because it encompasses both ends of the spectrum of expression and because the Spanish coloration is missing on the palette, In operatic terms, the figure of Celestina would introduce a new type - a female Falstaff, I cannot say it differently; it is, boldly speaking, a female buffo role, something unknown, as far as I know. Perhaps I will be able to suggest something else in two weeks when I have finished with the corrections of my book $^{7}$ and can think more clearly. ${ }^{8}$ (emphasis added)

Before proceeding further, a few statements in Zweig's letter call for commentary. First, for Zweig, Celestina was a work clearly molded in the dramatic tradition, the first such work of Spanish literature, antedating Calderon and Lope in whom Zweig, as well as Strauss, had been long interested. ${ }^{9}$ The work is, indeed, of a dramatic nature, having been composed, somewhat surprisingly, in pure prose dialogue (early Spanish theatre is almost always in verse): however, its twenty-one acts make it

6.- Richard Zoozmann, Die Celestina: Fernando de Rojas; eine Tragikomödie in 5 Aufzügen nach der dramatischen Novelle des spanischen Dichters. Dresden: H. Angermann, 1905. Almost completely unknown, this German version of the Spanish classic is the subject of a first-ever study: Fernando Carmona Ruiz, "La recepción de la Celestina en Alemania: su primera adaptación teatral (Richard Zoozmann, 1905)»; Celestinesca 29 (2005), 47-70.

7.- Zweig refers here to his Maria Stuart, a copy of which he will later present to Strauss.

8.- This quotation can be found on pp. 69-70 of A Confidential Matter: The Letters of Richard Strauss and Stefan Zweig, 1931-1935, ed. Willi Schuh \& translated by Max Knight (Berkeley, Los Angeles, London: Univ. of California Press, 1977). All subsequent English quotations from this correspondence are from this volume and by page number. The German originals can be consulted in Willi Schuh, ed. Richard Strauss-Stefan Zweig: Briefwechsel (Frankfurt am Main: J. Fischer Verlag, 1957).

9.- In a letter to Zweig of June 17, 1934, for example, Strauss clearly knew Lope's La judía de Toledo [The Jewess from Toledo]. For more on his fondness for Calderón, see Arno Gimber, "Calderón y Richard Strauss: La hija del aire - entre fatalidad finisecular y monstruosidad fascista,» in Calderón en Europa, ed. J. Huerta Calvo et al (Frankfurt-am-Main/Madrid: Iberoamericana - Vervuert, 2002), pp. 293-301. 
unwieldy for staging without a considerable amount of adapting. The matter of adapting the work was an idea - Zweig tells us - he had been pondering prior to 1935 , but now felt that Strauss, the consummate musician, could make it, literally, sing.

Second, as librettist for Strauss' The Silent Woman, Zweig is aware of Celestina's potential for a specifically musical treatment. Third, the character of Celestina is, musically speaking, envisioned as perfect for a female buffo role, an absolute operatic original, a twin, as it were, to Shakespeare's (and Verdi's operatic) Falstaff. ${ }^{10}$ Fourth, there is Zweig's remarkable insight that the two extremes of love (noble and crude) are in fact similar in essence, yet different in kind, linked in everyday life through the grotesque deformations caused, in an esperpento-like fashion, by a distorting mirror.

Although one is free to feel, as we do, that the author(s?) of the Tragicomedia de Calisto y Melibea (the original title of Celestina) would have roundly approved of such commentary — could they have read over Zweig's shoulders in 1935 - the simple truth is that neither Zweig nor Strauss knew the Celestina in its Spanish original (Gregor, however, did). Both came to know it through the German translation of Eduard von Bülow. However, the immediate appeal for Strauss was founded on his reading of Richard Zoozmann's verse adaptation, urged on him by Zweig, which we have also consulted. That versified German version of Celestina is crucial to our story as it mediated the exchanges of letters between Zweig and Strauss. ${ }^{11}$

Strauss answers Zweig's letter, cited above, from his home at Garmisch on April 2, 1935. Zweig's familiarity with Celestina, and the recommendation to Strauss that he read Zoozmann, has clearly piqued the composer's interest:

I shall write for Celestina at once. This material has possibilities. It's a matter of how to handle it and whether it is possible to create from the mentioned figures characters who interest us as human beings, not merely entertain us [on the opera stage] (...). (71, emphasis added)

10.- This resemblance between the two, Celestina and Falstaff, was also noted by L. Senelick in his «The Bawd and the Bard,» Prologue 30, number 2 (November 1974), p. 1.

11.- Von Bülow's original translation is Leipsig, 1843: Celestine. Ein dramatische Novelle. There was a new edition of this translation prepared by Lothar Schmidt (Munich: G. Müller, 1909). I do not know which edition Zweig and Strauss read, but it matters little. What is more arresting is that in the letters Zweig is recommending a verse rendering. In theory this could mean that its operatic potential, for the poet Zweig at least, was more evident in Zoozmann's verse adaptation of 1905. Recall that Zweig stated to Strauss that the work «can never be translated, only adapted» (70), and that the possibility of a musical adaptation to the lyric stage was what had intrigued him "for years» (69). 
While recognizing its musical "possibilities», Strauss seems initially more cautious, more concerned with characters that will be able to connect in a profound way with the opera-going public. Both Strauss' interest and his caution resurface in a second letter to Zweig, written just four days later, on April 6, 1935. This letter, reproduced below in its entirety, is devoted exclusively to the topic of Celestina, its characters and their operatic potential. Spanish scholars of Celestina need to be aware that Zoozmann's is a freely adapted version and that the added characters Strauss names here complement the originals of the Spanish Tragicomedia of Calisto y Melibea.

Dear Herr Zweig,

I've plowed through Celestina twice now. The figure of Celestina is indeed a brilliant part, but no more than a part, for a play that is even weaker that Die lustigen Weiber. ${ }^{12}$ Or rather, it is no play at all, but a succession of scenes, which, to be sure, are splendid (especially the first ones, with Celestina). Splendid, too, is the character of the matchmaker and, in part, also the characters of the underworld: Crito, Centurio, the three girls, Parmeno.

The lovers are rather conventional, but the love scenes include many beautiful thoughts and precious verses, fine material for a dramatic treatment that still has to be supplied. The upper and lower worlds are much too loosely connected, only at the beginning by Celestina and Parmeno/Ines, Luis/Ines, Sempronio/Elicia, and so on, who never get into direct dramatic conflict with the couple. The parents - a pale version of the Montagues and Capulets - are impossible, at least for the tragic ending, for which there is no reason because Pleberio, from the outset, is inclined to forgive the murder of his brother; hence the parents would have to be treated in a semihumorous vein, because Calisto's misunderstanding (that the murder of his [Pleberio's] brother is the reason for his not being able to marry Melibea) justifies neither the long secretive behavior, nor the flight, let alone the tragic end. The only one who could conceivably be murdered at the end would be Celestina or, possibly, Don Luis. But he, as well as Fabio, would have to be tied much closer to the plot; in a finale of the second act or at the end (as in Figaro) everything has to clash. (1849). 
It does not make sense that the three prostitutes are suddenly out to kill Calisto in the fifth act. Parmeno, seduced by Celestina, would at least have to betray his master. Above all, dear Herr Zweig, from all the excellent single scenes would have to be created a truly integrated plot culminating in a happy ending; and all similarity with the much stronger Romeo and Juliet story would have to be avoided. Do you think this possible? Much previous material is there, but an even half-way interesting plot would have to be invented. For example, Don Luis always talks about his hope to marry rich, but the tale just coasts along as a side issue until he gets murdered by chance. The Luis/Ines episode is good. As for Parmeno/Ines, a direct tie with the main story is missing. I wonder whether I express myself clearly. Fabio has no profile either! Could Melibea's assorted suitors not be shown in a great scene at the parents'? Or whatever else your vivid imagination whispers to you. You are right: Celestina's part alone is worth the work on this material. But the play must be better than Falstaff.

There is plenty of material for charming pieces - trios, sextets; just the connecting link is missing. Let me know soon about your further decisions. Best wishes, sincerely,

$$
\text { Dr. Richard Strauss (72-73) }
$$

Zweig's reply is not long in coming. From his quarters in Vienna's Hotel Regina on April 12, 1935, Zweig sends to Strauss a copy of his Maria Stuart, and adds:

I am delighted that you also see elements of an opera in Celestina. I like two things about it, first, juicy Celestina herself, who would be something new in the rigid realm of opera figures, a human being who radiates elementary exuberance and mirth; and secondly, the lover who in his unworldliness becomes the victim of those scoundrels. It's true, the plot is too primitive, it must be newly invented, and enlivened, as you say; the only usable part in it is Celestina, who couples the upper ethical-lyrical world so magnificently with the vulgar. I'll think it all over and will jot down a few things on paper, which you could then pass on to somebody to work on. (73-74) 
At this time, Strauss knew of Joseph Gregor and his work. ${ }^{13}$ Indeed, Zweig had already and privately encouraged Gregor - one person he thought would make a fine "somebody" for Strauss to work with - to begin work on a scenario for an opera of Semiramis, based on a play by the seventeenth century Spanish dramatist, Calderón de la Barca (d. 1681). But Strauss did not return to Zweig's Celestina project in writing until, in a letter composed in Bad Kissengen and dated May 4, 1935, he first expresses some personal doubts about Gregor's abilities as a librettist.

\section{Dear Herr Zweig,}

Gregor wrote me a very cordial letter. I am most anxious to learn what you two have cooked up [vis-a-vis Semiramis]. I am not so sure about Gregor as I am about my proved and tested Zweig, and am therefore asking, first, for your active participation in Semiramis and, second, that you do not abandon our two previous ideas: 1648 and Dopo la musica ${ }^{14}$; nor Celestina, which would interest me very much if you could succeed in creating a good, complete tragicomic comedy, to supplement the romantic pair and the magnificent matchmake . (87)

Not only was Strauss not forgetting their exchange of ideas on a "tragicomic comedy" to be based on Zoozmann's Celestina, he was also not about to let Zweig shunt the actual preparation of the text off onto someone else, and thus remain in the shadows as an anonymous source of «assistance».

Later in May, on the 24th and from his home in Garmisch, Strauss again urges on Zweig the Celestina project. First of all, Strauss reminds his friend that only he [Zweig] can be counted on to spin operatic gold from Calderón's Semiramis, appealing to him as «a real poet and creative theater expert.» He then changes the subject to Celestina:

I also consider Celestina possible, if fashioned by your hand; and, likewise, I would welcome any material created by yourself. But don't you recommend any other librettist to me. Nothing comes of it; it isn't worth the paper. (96, emphasis added)

13.- In a letter dated January 24, 1934, Strauss had recommended for Zweig's further reading sections of Gregor's Weltgeschichte des Theaters, which had appeared only the year before (Vienna: Phaidon, 1933).

14.- Both of these Zweig-Strauss projects ended up as successfully-produced operas with other librettists: 1648 with Calderon's "La rendición de Breda" as its source, is produced as Friedenstag (1938) with a libretto by Gregor; and [Poi le parole] Dopo la musica becomes Capriccio (1938) for which Clemens Krauss worked on the finished libretto with Strauss. Celestina, we know, was the only one of the three projects mentioned here that never made it to the musical stage. 
In the following months, their published letters are silent on Celestina. Occupied with other projects, Zweig seems to have let the idea of a Celestina libretto founder. In October it is Strauss who brings the matter up again. In a letter dated All Hallows Eve of 1935 from Garmisch, Strauss is praising the workable stage version Zweig has given him for Friedenstag, in particular preferring it over the more prolix version produced for him by Gregor. Evidently, Strauss is still somewhat nettled by Zweig's protests, finding it difficult to convince him to produce something original for him and again pleads with him:

Wouldn't you yourself work on something for me? Celestina, and Poi le parole, doppo la musica? (104)

Both of these projects had been encouraged on Zweig in Strauss' letter of May 4th, but Celestina is mentioned in other letters as well.

For Zweig, other than the fear that their association, if generally known, and especially after the scorn that ensued following their collaboration on Die schweigsame Frau, would bring harm and possibly opprobrium to the good name of his friend, Strauss, we can, additionally, further speculate as to why he desisted from work on an opera, Celestina, that he had initially himself proposed so enthusiastically to the composer. We suspect that Zweig would only consider working on a libretto for Celestina if Strauss would be its composer. The racist debacle with Die schweigsame Frau, if it had left Zweig discouraged about the real possibilities of future collaborations - as it surely must have done-, it must also have tempered Zweig's enthusiasm for taking up in earnest any work on his proposed adaptation of Celestina. Zweig's recurring solution was to have Joseph Gregor replace him, and to have - however distasteful it might prove to the composer- Strauss accept such an arrangement. Whatever scenario we might wish to imagine, it is clear that as 1935 wore on, the momentum for the Celestina project clearly had passed from Zweig, who initiated it, to Strauss, who pursued it.

In a postscript to the All Hallows Eve letter, Strauss' praise and beseeching tone make this clear:

You are kind and self-effacing in yielding your authorship to good old Gr[egor], and you are considerate toward me, but I simply won't believe it and Gr. does not have what it takes for a suitable libretto. So I am asking you again, do the play yourself, and also Celestine if possible, which could make a very merry affair, if done by the right person. The character itself is delicious and the lyric elements superb. I promise profound discretion. (105, emphasis added) 
Clearly, Strauss at this point was willing to consider only Zweig as «the right person", since he deemed Gregor lacking in the skills to produce a "suitable libretto». Since the topic is not mentioned again in the ZweigStrauss correspondence, some or all of the following: politics, race, friendship, fear, and caution, must have intervened — sadly — to prevent Stefan Zweig, in 1935, from ever realizing a second opera libretto for a Richard Strauss opera, one based on Celestina. And without a well-constructed dramatic plot to guide him, Strauss, who was anxious and eager (as we have seen, even in old age) to write the music for this Celestina opera, was left holding on to an unrealized clutch of musical ideas. ${ }^{15}$

\section{July-October 1936}

Joseph Gregor, after six weeks of work by Zweig to bring it about, finally met with Richard Strauss on July 7, 1935, in the Berchtesgaden. ${ }^{16}$ This was a month after the disaster in Dresden of Die schweigsame Frau and, as already noted, the day following Strauss' forced resignation as president of the Reichsmusikkammer. It is almost certain they spoke of Semiramis, another work inspired by the Spanish dramatist, Calderón de la Barca, and also of his La hija del aire. Hugo von Hofmannsthal had earlier piqued Strauss' musical interest in this grand, grotesque figure and drafted a sketch for a libretto. Now Gregor, encouraged by Zweig - who assuredly knew of Hofmannsthal's earlier work on Semiramis - was also working on it. It may have been part of Zweig's plan to bring the two together, to make Gregor more appealing to Strauss as a collaborator-librettist. What is clear from Gregor's letter to Strauss of June 6, 1935, one month after the initial meeting, is that Gregor is utterly disposed to work on whatever Strauss wants: «I want to continue working, perhaps on a Spanish masterpiece, Celestina, or with even greater pleasure, Semiramis. If you need me, please call on me [...]. Yours, Gregor.» ${ }^{17}$

15.- Even though the Celestina project never did materialize into a Strauss opera, it is evident that Zweig's influence on the composer was not insignificant in this particular musical project, especially considering Strauss' enthusiasm for it. For this reason, I find it disappointing not to have encountered a single mention of this matter in Bryan Gilliam, "Zweig's Contribution to Strauss after Die Schweigsame Frau: New Evidence," in Stefan Zweig: The World of Yesterday's Humanist Today (Proceedings of the Stefan Zweig Symposium), ed. M. Sonnenfeld (Albany: SUNY Press, 1983), 217-226. But as noted in our Prologue, this sin of omission is frequent in Strauss biographies.

16.- Gregor's account of his first meeting with Strauss is found in his Richard Strauss. Der Meister der Oper. Mit Briefen des Komponisten u. 30 Bildern (Munich: Piper, 1939), pp. 246-247.

17.- The German texts of which these are translations (by Snow and Gimber) are found in Roland Tenschert, ed. Richard Strauss und Joseph Gregor. Briefwechsel, 1934-1949, Salzburg: Otto Müller Verlag, 1955. Page numbers refer to this edition. The original of this citation is from pp. 64-65. 
Strauss, keen to take up the "possibilities» of Celestina once again, devotes most all of his reply, dated three days later (June 23rd) in Garmisch, to the topic:

On Celestina, I have concerned myself intensely in recent days with the two German versions (Zoozmann and the more literal translation of Eduard von Bülow). I've imagined a good finale for Act I, with Celestina alone after her visit to the home of Melibea. The end of the second act: the definitive meeting of the two lovers. The scene preceding this and the one with Celestina's death could be effective, too. Still, the end!!? At first, I was not ready to have the lovers end in tragedy and was seeking a happy solution, perhaps an elopement. A wedding with the parents' blessing would be too banal. I continue to read Bülow, a bit overlong, and have seen that Calisto falls from a ladder and that Melibea throws herself from the high tower: suddenly I understand that the stage adaptation (more the music than the dialogue) is possible only if the poetic characters of the work - the father, Fabio and the lovers- are treated parodically.

The lower class characters can remain as is - they are already caricatures- but Zoozmann has discovered poetry in the lovers and has furnished them with beautiful verses and sentiments without realizing that the deaths of the lovers is thus brutal and unmotivated, a situation that has bothered me from the beginning.

But now I see in Bülow that above all else Calisto is treated from the outset as a fool (especially in his conversations with Celestina) and now I see fully the character of this Spanish tragicomedy. ${ }^{18}$ And if we succeed in maintaining a tragicomic style as well in the love scenes with a false pathos intermixed with truly poetic moments, then it will be seen that Calisto can only fall from the ladder. The parents should as well be presented as the reverse of the Capulets - all of it as a satire of Romeo. ${ }^{19}$

18.- This intuition of Strauss' is shared by the majority of Celestina's literary critics as well. Calisto is seen as a parody of the medieval courtly lover as early as the article by Alan Deyermond, "The Text-Book Mishandled: Andreas Capellanus and the Opening Scene of La Celestina,» Neophilologus 45 (1961), 218-221.

19.- Of course Celestina precedes Shakespeare's work by a century but Strauss is thinking of how to resolve certain issues for his operatic version of the work and, in doing so, provides an important insight into Celestina that its literary critics - too prone to see similarities and, therefore, possible influences of the earlier work on Shakespeare- would do well to reflect 
It would a continuation of the ironic style of Così fan tutte and the perfection of the mockery undertaken in Feuersnot. ${ }^{20}$

So it will be possible only if we give it a grotesque treatment. Then the original ending will be justified

Would you like to try it again in this light? Zoozmann's version, which highlights that which is the essence, has many advantages, except that from the time of the death of Don Luis, you should tie the knot tight with the help of a great scene of chaos involving directly the antagonists: the parents and Fabio. (65-66)

Strauss writes this just as he has finished the musical score for Friedenstag, the one-act opera for which Gregor was the official librettist but in which, we know, Zweig had helped with several drafts. Strauss is free to think about this Celestina and, just a day later, on June 24, 1935, writes to Gregor that "Celestina has the disadvantage that this central character, as a tragic figure, anticipates the housewife of Die Frau ohne Schatten, one further reason why it all must be treated in a grotesque manner» (67).

Gregor's response to both these missives comes two days later, on June 26, 1935 from Vienna. After offering congratulations to Strauss on his having finished Friedenstag, he feels he cannot agree fully on certain other matters with the composer.

I see Celestina, nevertheless, as very different from the housewife of Die Frau ohne Schatten. The latter grows heroic in the intrigue [of the work], in the [matter of] evil, she is evil personified, a figure from Hades. Celestina, on the other hand, is entirely of this world. Her raffishness, her sarcastic triumph over love, her burlesque witchcraft all grow gigantic, they become sinister, but never heroic, which the housewife always is. The housewife is a spirit, Celestina is the negation of the spirit in her dark dwelling on the outskirts of the Spanish urban center where she exercises her multiple professions. Precisely the fact that Celestina comes from such a low social milieu gives her a sinister grandeur, but she is ever a realistic go-between. She never becomes - as does the housewife- a metaphysical go-between with profound objectives.

A favor: unhappily I cannot obtain either of the two versions, not Bülow's nor Zoozmann's. I have only read

upon.

20.- Here Strauss alludes to his own piece from 1901. 
the Spanish original ${ }^{21}$ and the contemporary German translation in Old German. In the National Library [of Vienna $]^{22}$ they cannot locate either version and it would take a long time, too long, to have them searched. Would you be so kind as to send them to me by certified mail? Then I will concentrate on both topics, Danae and Celestina and send you draft librettos of both. Afterwards, I will return both books. (68)

Ten days later, Gregor will remind Strauss of this book request. From Vienna, he writes on July 7, 1936 to the composer: «In my previous letter, distinguished Dr., I requested the two versions of Celestina by Bülow and Zoozmann. If there are problems, please let me know; I wish only to save myself the complicated search for them and would return them directly I have finished reading them» (69). Gregor is evidently eager, having previously read only the Spanish original, to read the German translation and verse adaptation that have shaped Strauss' thinking on the matter of $\mathrm{Ce}$ lestina. In modern parlance, he deemed it best that both be "singing from the same hymnal.»

Strauss responds four days later to this urgency, on July 10, 1936, from Garmisch:

Esteemed friend Gregor:

I am sending you the two Celestinas. Zoozmann's version has many advantages, but the ends of the acts must be changed. Act I must end with a grand demoniacal monologue by Celestina, having been once or twice to the house of Melibea. Act II [must end] with a grand love duet, and Act III with the denouement of the action, a montage with the parents, Fabio, Don Luis - something akin to a second end to Figaro, act IV-, the death of Celestina and the end of the pair of lovers. It will be difficult to create a work in just three acts and, at the same time, provide a complete dramatic nucleus with all its tensions. (70)

It is now, in the ensuing three weeks, that Gregor quickly peruses and absorbs the von Bülow and Zoozmann Celestinas and writes the draft he will send to Strauss. In it, he hopes to have provided a solid scaffold for

21.- Gregor, a historian of world theater, incorporates his reading of and reflections on the Spanish original in his Das spanische Welttheater (Munich: R. Piper \& Co., 1937), pp. 9397. These have helped modify considerably many of the notions expressed by Strauss in his comments to Zweig (see the letter of April 6, 1935, cited above), based solely on the two German works - translation of Bülow and adaptation of Zoozmann - he has read.

22.- Joseph Gregor was then the director of the theater section of Vienna's National Library. 
the dramatic nucleus that would result in a Celestina opera. We present our English translation of Gregor's ten-page sketch in Appendix I. It reposes in - and each of its pages bears the circular stamp of - the "Strauss Archiv. Garmisch» (Illustration 1). Evidently Strauss preserved it against, perhaps, a better day. As the letter from Gregor to Strauss accompanying the sketch for Celestina is a long one, we quote it here in full because it is devoted exclusively to the project.

\section{Esteemed Herr Dr.:}

With great pleasure I have written a version of Celestina for the stage and include it with this letter. I have read both books. Bülow's translation complicates the original a little and lacks its freshness. Zoozmann correctly saw that new characters needed to be added in order to convert this dramatic novel into a drama. Nevertheless, he erred completely in the election of these new characters. ${ }^{23}$ You, Herr Dr., have correctly understood that the original already treated Calisto as ironic. He is a bland hero and even to this day the name Calisto means in Spanish literature something like effeminate hero. ${ }^{24}$ Such a one can only, evidently, fall from a ladder. To have him die in a great duel, as Zoozmann has done, is a travesty.

I have maintained the division of action in the acts as you have proposed them and I believe there will be a great effect in [the finale of] the third act. I imagine the language as crisp and short, using prose as in the original and occasionally adding in some short verses. In its totality, the work must openly avow a spirit of full irony. Meaning is lacking if we adhere to pretty and pathosladen forms, as does Zoozmann. It is only Melibea that I wish to leave as sympathetic until the end. This unique character, let her be the negation of the go-between's triumph, this young girl, faithful and full of love with

23.- Gregor has replaced, in the sketch submitted to Strauss, many of Zoozmann's additional characters (Luis, Fabio, Inés) with others of his own invention (Hippolytus, Flores, Virginius) but he adhered more closely to the general plot lines of the original Spanish tragicomedy.

24.- Where this notion arises is unknown. The original Calisto is written as well-to-do, vain, and impulsive, to be sure, perhaps even immature. His name, deriving from the Greek, means 'beautiful' or 'handsome', but we have not seen "effeminate» as a characteristic applied to him. 
a disposition not unlike an authentic Juliet. ${ }^{25}$ It is her ill fortune to have met Calisto and it is this misfortune that allows Celestina to triumph. Still, it will be necessary to maintain Melibea as pure so that it will allow for Celestina's witchlike character to seem even greater and, furthmore, to [finally] destroy her at the end. Only in the death of Melibea do we find ourselves liberated from the ghost of Celestina.

Hippolitus is more human than Calisto, although not completely; he is fully content with the imaginary vision of Melibea. In the drama, there can be no strong male character, since to have one would likely upset Celestina's machinations. They are all half men and women, always excepting the character of Melibea. Owing to her extreme youth she fell momentarily under the spells of Celestina and then completes her penitence with her suicide.

I'll be interested in what you say and await your opinion, as I said, here in Vienna. Much in the work remains hidden and I would be greatly pleased to have fulfilled your intentions.

$$
\text { Cordially, G. (70-71) }
$$

The treatment given Celestina in this letter is the surest indication that this opera was more than a passing fancy. The project was being advanced enthusiastically by both men. In just four short days, Strauss had read through the version Gregor had sent and his pen was ready with an answer. He writes from Garmisch on July 27th, 1936, the following reaction:

Dear friend Gregor:

[...] Your Celestina pleases me a great deal: it could become a magnificent tragicomedy. Sinister. Except Virginius who does not please me so much. But the rest of the characterizations are excellent. The lovers are possible only in the ways you propose and the finale is well motivated. It may be that a few exaggerated bits might need to be excised (the courtesan-like mourning of the go-between, the flags draped throughout the city, etc.). I advise you only to build on this sketch immediately, first,

25.- What is certain in the original Celestina is that Melibea, alone of all the characters, never sees Calisto as a "fool» or a parodic lover. She is as immersed in a literary notion of love as is Calisto, but also indulges her newly awakened passions as fully as does her lover. It may be that Gregor idealizes her, since she is manifestly a stronger character, with greater self-knowledge, than is Calisto. Perhaps it is her resolute firmness in "love» that sparks this comparison to Juliet. 
without thinking about the musical accompaniment except perhaps the lyrical scenes you have in verse form, but the rest, in prose, utilizing if possible, the magnificent Spanish dialogue. (72)

And in about seven days, it is Gregor who, writing from Vienna on August 3rd, expresses his great content at Strauss's enthusiastic encouragement: «Much esteemed and dear Doctor: I thank you very much for your benevolent reply and am enormously delighted that the sketch for Celestina has pleased you. I promise you I will carry this on to the next stage according to your indications» (73).

But a month passes and unknown factors seem to be at work behind the scenes. Owing to the pressure of other obligations or commitments at this precise moment, there is no immediate work on this «next stage.» When Gregor writes again to Strauss, on the last day of August, 1936, it is to state, with regard to their Celestina, the following: «I have a great desire to rest and will go to Gastein to write there the opening scenes of Celestina. I wish you could be there as well. It would be marvelous» (74).

There is now yet another time lapse, at least with written references to Celestina. Nearly two months pass when on October 24, 1936, writing from Garmisch, Strauss broaches the topic again. He writes to Gregor, stating apologetically:

Esteemed friend: Unfortunately, I must cancel the meeting planned for Bozen: we are traveling by train to Rome. We could postpone our meeting in Garmisch until Christmas week. In the meantime you could send me what you have worked up already on C[elestina]. (75)

Unfortunately for posterity, the written record on Celestina falls silent after this letter, and what might have emerged finally from a StraussZweig-Gregor collaboration on their Celestina opera is, of course, unknowable. What Gregor may have "worked up» by then, and possibly later, is a matter for speculation, as is any musical composition by Strauss. We are left at this point to ponder wistfully how much richer the spectrum of operatic adaptations of Celestina in the twentieth century (see our Appendix II) might have been had both of these men -Richard Strauss and Joseph Gregor- continued to work through their ideas and bring them to fruition for the operatic stage. The atmosphere of pre-war Germany in 1935 and 1936 almost willed that Stefan Zweig, the Jewish poet from Austria, the Austrian born and German-based composer and conductor, Richard Strauss, and the Austrian theater historian and Strauss librettist on three occasions, Josef Gregor, should remain - to the detriment of their new operatic concept of Celestina- star-crossed collaborators. 


\section{Appendix I. \\ Joseph Gregor's Sketch for the proposed Strauss-Gregor Celestina Opera.}

[N.B. The ten-page sketch for the three acts was produced on a typewriter. The first of its pages is the only one with no corrections, suppressions, additions (a few by hand), underscores and emendations. It has remained unpublished for almost seventy years.]

\section{Celestina}

ACT I. sc. i. Inside Calisto's house. There is on stage a slow, sleepy mood, as a folk song [a copla] is heard. It is Seville on a summer morning. Some servants are speaking idly among themselves. They are unable to bear any longer their master's unhappy love pangs. The master sends then scurrying here and there, bearing gifts and letters that go unanswered. Their parley languishes. At this moment, the sounds of a parodic love romanza sung by Calisto are heard. The servants look at each other: They are alarmed: he's at it again, singing away! They feel they must do something. Sempronio, the most familiar with the stock-in-trade of Celestina, proposes to seek out her all-powerful arts, but Pármeno is sharply dismissive of this solution. Tristan, who is deaf, votes for taking in a bullfight; the simpleton, Sosia, feels they should adjourn to get some wine. They exchange counsels and even throw the dice to see what counsel they can offer [in the background there are strains of a popular song] concerning the fate of their master. The music changes abruptly and the servants arise fleetly: they can smell old Celestina approaching. I envision her musical theme as a wild caricature of a saraband. The servants are assured it is Celestina: her odor precedes her. They rush to the window. Voila! It is the very bawd passing by trailing her well-worn skirts, an enormous scar decorating her nose. The servants are afraid to pronounce her name. Just then, drifting down from above, weak and morose, comes the monotone of Calisto's ballad (romanza).

Too late! Celestina has approached the door. She too has sniffed out the work there is for her in this place. She treats the servants with disdain and sends Tristan and Sosia away. Familiar with all kinds of lover's tales, she is impatient with Calisto's. Yet, she signs and seals a pact with Sempronio and Pármeno as to how they will split up any profit from their joint dealings. Sempronio goes off to put Calisto in the picture and the singing soon stops. Pármeno knows how devious Celestina can be and argues strenuously with her. Celestina decides to be nice to Pármeno and invites him to come later to her house. 
The entrance of Calisto, entoning his beautiful romanza. He is a handsome man, with curly hair and moustaches, puffed sleeves, and wearing a sash. He tells Celestina the tale, almost breaking into tears, of his encounter with the fair Melibea and the curse she placed on him, promising that he should never see her again. He is obviously devastated by his fate, but Celestina can scarcely contain her amusement. She (against the music of a savage saraband) explains her services to him: his case is an insignificant challenge for her arts. Calisto drops into her hands clinking gold coins [20 thalers]. Peeking out of apertures and hiding holes are the caricaturesque faces of the servants, who witness this financial exchange singing a grotesque rondelay: ten ducats are in the bag for each! ${ }^{26}$ Change of scene.

Scene ii. Inside Pleberio's house. The parents are speaking, preoccupied. Calisto's attempts to speak with Melibea are known to them. ${ }^{27} \mathrm{He}$ possesses wealth but is of the lower nobility, of even less valor and with an inferior intelligence. He has even been banished from court. They must confirm Melibea in her strong abhorrence for Calisto. The father, a vain man with a slow wit, prefers placing her in a convent. The lavishly dressed mother, loquacious of speech, is taken aback at this, for Melibea is but sixteen years old. No, better an early marriage: Hippolytus, a gentleman of the upper nobility, clever, the opposite of Calisto in all things except, unfortunately, money. The mother's thoughts seem heaven-sent, for at this very moment, a servant announces the visit of Hippolytus. Indeed, he is seen to be the opposite of Calisto, a true gentlemanly figure. He relates in a lilting romanza his impressions of his own initial meeting with Melibea, speaking of all her praiseworthy virtues. The mother is increasingly affected; the father increasingly rigid and pedantic. There is a brief conference between the parents: it is crucial to distance Melibea from Calisto, and to gain some time. While this Hippolytus might serve very well, there is the question of... money... Money! They resolve it thus: Hippolytus is not to see Melibea for six months and then, if the love he professes is still as strong as it is now, then that will be time enough to come to a final decision. Hippolytus swears to abide by the agreement and the parents depart with a solemn seriousness. Hippolytus remains on stage singing with deeply felt sentiments, caressing the door

26.- With the exception of the roles assigned this early to Tristan and Sosia, the actions outlined here roughly conform to that of Celestina's long Act I (approximately $25 \%$ of the full text). Some action is condensed, of course, particularly Celestina's happening upon the scene, instead of being summoned by Sempronio.

27.- This scene contains many radical innovations. In the original the parents are the last to know about the affairs of the lovers. There is never any second suitor for Melibea, and Melibea quickly accepts her new feelings of strong passion for Calisto and allows Celestina to act as a facilitator for bringing them to fruition. Some of these departures from the original Celestina are motivated by Zoozmann's poetic adaptation and the agreed upon need for the addition of new characters. 
behind which lies the most precious jewel in this world which, despite his sworn oath, could be surrendered to him (...)

The door opens and Celestina, ever like a phantom, enters the room. Hippolytus is taken aback. She again knows instinctively that this fellow could easily become her fiercest enemy. And she inquires of him unctuously why he never visits her, poor woman that she is, why he never casts a glance her way. Hippolytus answers that he should now have ample time to do so. She easily pries out of him that he has just sworn not to seek out Melibea for six months although his heart is about to break with anguish. Her reaction is instantaneous: she offers him a potion effective against the pangs of love. He is wary, but Celestina has made a beginning with him. He leaves, filled with suspicions about he .

Lucretia. Her mistress. The two older women get along swimmingly. Unhesitatingly, Celestina offers her half the profit she plans to make from this business. They must provide clandestine access for Calisto, and find clever ways to prevent Hippolytus from having access. And Melibea? Celestina will see to her. Into this scene of sorcery Melibea enters, a radiant sun.

Melibea is genuine, dark, like Juliet. She has instinctive sentiments against Celestina, for whom she feels an aversion. She does not love Calisto and has scarcely gotten to know Hippolytus. But she is inwardly mature. Celestina can begin with her magical games. There is a grand scene: gradually the grotesque saraband [Celestina's theme] drowns out the softer childlike notes of Melibea's theme. The crone succeeds in obtaining Melibea's girdle and even more, a portrait, a shawl, jewels and a lock of her hair. The audience feels Melibea is disposed to give anything. Celestina excuses herself humbly, bearing away her borrowed treasures. Melibea's words ring true: she loves not this knight [Calisto] but does feel compassion for him. She will pray for him. Throughout her prayer, we hear the Mephistophelian laughter of the departing go-between. Change of scene.

Scene iii. A chapel. Calisto is praying before the image of the Purísima; Pármeno stands behind him. The music first echoes Melibea's prayer, then his own, then Celestinás laughter as she is tiptoeing closer to the praying Calisto. She hands to him Melibea's girdle, her cameo portrait, and the rest. These things have been sent by the Virgin through the mediation of Celestina. Calisto is thrilled and caresses them with great enthusiasm, as his prayer music blends into his romanza. There is ever something feminine about Calisto. He promptly remunerates Celestina with a great gold chain and promises even more to come. He departs filled with hope. Then Pármeno, hidden in the shadows, emerges and pushes Celestina: Deceitful crone! Celestina at once begins to melt this anger: Sweet, dear Pármeno, if you were to join with me ... But he harshly demands his portion of the profit and threatens her with denunciation as a go-be- 
tween and witch. She, for her part, casts a spell on the young innocent: were he to join her, she would reward him with something more pleasing than all the world's vile ducats. Pármeno follows with reluctance. The saraband of the crone sounds again, triumphant. Change of scene. ${ }^{28}$

Scene iv. Areúsa's chamber. She is reclining in her bed and dreams of her many lovers. As she recreates these lovely moments, a seguidilla is being played. Like a shadow, Celestina enters soundlessly. A small yelp escapes from the prostitute, frightened. Celestina soothes her, saying she had only thought to bring with her -pointing to the door- some beneficial consolation. Areúsa, afraid of Celestina, wants to know nothing of this. Caressing her, Celestina praises her great beauty. Sounds of admiration from Pármeno, whose lust can scarcely be contained, can be detected through the door. Celestina forges ahead with her erotic magic. At the moment when the music of the saraband is triumphant, Pármeno rushes upon the supine Areúsa. There is diabolic laughter from Celestina, shouts from Areúsa. [This scene, perhaps the most grandiose, the most sinister from the original work, ought be maintained with the greatest fidelity possibl ${ }^{29}$.] Change of scene.

Scene v. Celestina's house. Conceals nooks, many doors, the paraphernalia of magic scattered about. Elicia and Sempronio. The latter is telling of Calisto's progress with Melibea and he himself is almost content, as Celestina has reunited him with Elicia and her favors. Somehow, she puts off the satisfying of his demands. In this moment, the deceiver, Centurio, enters with a new member of the merry band, little Flores. She is seventeen and reminds one of Melibea: pure. Centurio is an overweight pimp, gross in all ways. All the prostitutes disparage him. He earns his living seeing that Celestina gets a new supply of girls. There is yet another member of this confederation, the knight Virgilius, who approaches the girls with a flirtatious manne, but he is clearly impotent.

Celestina enters (the music of a loa). She orders up some wine and gets a party under way. Her hawk-like gaze penetrates the gloom and espies little Flores: my dear, I will see you obtain great favors. I have assured myself of victory with Melibea, and now have but to draw Hippolytus into love's labyrinth! Centurio, Sempronio and Virginius laud Celestina each in his own way. Then, at the culminating moment, a door opens and there stand Pármeno and Areúsa, all entwined. The bawd grotesquely blesses the new couple and says that like them there will be many others. The atmosphere grows wilder by the minute, the revelry and drunkenness more palpable as the bawd tells of her triumphs. Then Lu-

28.- Gregor cleverly condenses the action of the original drama by combing here bits of Acts I, VI and XI to form this operatic sequence.

29.- Indeed, the action described by Gregor almost exactly replicates most of Celestina's Act VII. 
cretia, a new guest, arrives, and declares that Melibea urgently needs to see Celestina. The music of the saraband increases in volume and there is sarcastic laughter from Celestina. Her wine cup in hand, she climbs upon the table to begin her conjuration of the devil. Below here, an octet of tipsy companions, Lucretia in Centurio's embrace, Pármeno with Areúsa, Sempronio with Elicia, and Virgilius pawing little Flores with the initial movements of seduction. At the apogee of the triumphal song of Celestina, she emits a curse upon the house and all its doors fly open, life springs up in every corner: there is a king, a friar, a plutocrat dressed in gold, a beggar, a plague-stricken fellow, all of them dancing madly by in the arms of prostitutes! The bawd keeps rhythm with her sarcastic laughter, much like the figure of death in the Danses Macabres. A triumphal chorus rises. [end of act $]^{30}$

ACT II, scene i. Pleberio's house. It is night and we hear lamentations from Melibea. She feels totally bereft, ill, but can't say why. The spell is working. My peace has flown ${ }^{31}$ Lucretia, preoccupied, dashes back and forth. Either the father, unsuspecting, appears or we only hear the voices of both parents, speaking off. When there finally is silence, Celestina emerges from the shadows like an owl. Melibea's attitude toward her has now reversed itself, and she falls on her knees before Celestina, imploring her help. The latter, delighted, continues to weave her spells. She tells Melibea what young men are like, but this version is different from the one she used with Areúsa. Again we hear Melibea's parents' voices, agitated. By means of her spells, Celestina causes them to fall deeply asleep..$^{22}$ When all is ready - and in a moment of great tension-, Celestina lifts the balcony curtain and Calisto rushes in..$^{33}$

Love duet that follows, generally, these ideas: May love be praised, whatever its provenance, it is beautiful even at the hands of Celestina. Calisto's figure seems to grow in the presence of Melibea's simple and pure nature. They kiss. Change of scene.

Scene ii. The garden adjacent to Pleberio's house. An owl flutters and takes flight noiselessly, like a grotesque and sinister Branwen, hovering over the joy of the lovers, which consumes them happily. Duet fragments heard. All of a sudden, yet another figure emerges from the shad-

30.- Some parts of Acts III and IX of Celestina are combined here, but many new couplings and new characters have been added. Areúsa's stature as an independent operator is reduced and Centurio's role is expanded.

31.- These words ("Meine Ruh ist hin») are an obvious echo of those pronounced by Marguerite in Goethe's Faust.

32.- This deep sleep is yet another reminiscence of Faust, with which Gregor clearly associates the actions here in his sketch for Celestina.

33.- Gregor combines scenes from Acts X and XIV and condenses the action of Celestina by not presenting the original's postponement (Act XII) of the lover's first physical encounter. 
ows: Hippolytus. He is tortured by the display of Melibea's desire. He sees two shapes fleeing, and in the distance there are the themes of the two lovers, and he becomes befuddled. In the moment when he must decide whether to enter the house, an owl [image of Celestina] swoops down on him: "Why does he not pay her a visit?» Away! begone, you witch! But age possesses wiles that youth does not know: thanks to her powers, Melibea could even yet this night find herself in his [Hippolytus'] arms. Tortured thus by love's pangs, and aroused by the sounds of love in the magic of this night in Seville, Hippolytus decides at last to heed the bawd. She leads him off as from above the love duet fades. ${ }^{34}$ Change of scene.

Scene iii. Flores' chamber. Celestina enters and wakens her: a client has arrived. Celestina begins to make the girl ready, brushing her hair, applying some make-up so that she will look just like Melibea. As if by magic, in the flickering light of the candle, there is born a second Melibea! Celestina instructs her with her infernal counsel as to how she must behave to become Melibea. Hippolytus calls out insistently, demanding that Celestina keep her word. Celestina, rushing now, pushes little Flores, now transformed into the beautiful Melibea, outside. But she remains, near the open door, listening. Change of scene.

Scene iv. A dark balcony, lit only by moonlight. Soft calls of longing from Hippolytus to Melibea. Flores passes slowly from column to column and the spectator cannot tell her from [the real] Melibea. Shadowing the scene is a sinister figure: Celestina. Hippolytus recognizes the work of the crone in this and is shocked. Is this his beloved or not? Celestina calls to him animatedly, urging him not to be foolish and to take what is being offered to him. An extended aria from Hippolytus, detailing his curious mood. Finally Flores draws near. No, not Melibea, but almost; her hesitancy arouses the man mightily: she is still a virgin.

Love Duet; great praise to Love, whatever its source, even at the hand of Celestina. A kiss; then the diabolic laughter of Celestina, and the familiar strains of her saraband. Change of scene.

Scene v. Calisto's house, as in Act I, scene i. The servants are again arguing ill humoredly, and there is heard the melody of the sentimental romanza with a variant tone that communicates satisfaction. Sempronio and Pármeno raise their clenched fists; they, rather, are highly discontent. They have not yet seen one penny for all their work. Too, they are unhappy that Celestina proposes to pay them, in part, with the company of the whores Elicia and Areúsa, while Hippolytus get to enjoy the favors of Flores. Calisto will be made to pay for this. Their attempts to open his eyes have been frustrated because Calisto has told them it is all the same

34.- Gregor continues with Zoozmann, as the original Celestina has none of this action, or of that of the next two scenes. 
to him how many Melibeas there may be, since he has been guaranteed to possess the true Melibea. Just then the grande dame, Celestina, appears, dressed elegantly in overdone velvet. There is annoyance shown by the servants; exaggerated and courtly deference by Calisto. No sooner does Calisto step out than the servants are upon her, demanding their share of the profits. She mocks them, even threatening to report them to the authorities since they treat her thus. Impotent fury of the ridiculed servants, as we hear a final triumphal song of Celestina, who can barely walk under the weight of her gold. ${ }^{35}$ Change of scene.

Scene vi. Celestina's house, more upscale now with her new wealth. Centurio and Virginius are serving as butlers, and the prostitutes are dressed in expensive, fancy clothing. Hippolytus, overwrought and brutish, enters and demands to see Flores. He takes her into one of the bedrooms. Sempronio and Pármeno arrive, carrying lances, ready for a brawl. The station themselves in front of the bedroom and sing risque songs that mention Hippolytus' pleasure in the disguised Flores while the real Melibea rests in the embraces of Calisto. Hippolytus, half naked, emerges with his sword drawn and gives them a fright. He sings, cynically, to the strains of a saraband, that [the real] Melibea no longer appeals to him, not by comparison with the real happiness Celestina has obtained for him [in Flores]. The two servants grow angry and Elicia and Areúsa are hard-pressed to calm them. We are close to a general fracas.

At this juncture, Celestina makes her entrance, as though she were royalty. She orders calm and gathers round her all the faithful. Lucretia enters again and reveals that Calisto and Melibea are deep into their tryst. She asks for money. At this instant, it is seen that a false Melibea (Flores) reclines in the embrace of a drunken Hippolytus. There is a reprise of Celestina's theme, in praise of her great powers. Sempronio and Pármeno have become furious; either Celestina compensates them now or they inform the police against the witch. A melée ensues.

Hippolytus, Centurio and Virginius block the door. The women scream. Outside, we hear the police and a chorus of the neighbors, alarmed.

There is a new attempt by Celestina to control the situation. In vain, however, as the desire for money proves stronger. In the instant when the door is broken down from the outside, Pármeno stabs Celestina. The gendarmes storming in arrest Sempronio and Pármeno, but Hippolytus manages to escape.

Celestina dies. She expires with a curse on the love which has cost her her life and brought only pleasure to others. She is celebrated in song as an authentic benefactress of humanity by a chorus of gendarmes, pros-

35.- Gregor retains from Celestina the growing dissatisfactions of the servants with Celestina's failure to share with them the gifts from Calisto, but Celestina is never portrayed making such opulent show of her new wealth. 
titutes, local officials and townsfolk, and the lynching of the assassins is proclaimed. The final ironic chorus proclaims that the great protectress of love has expired..$^{36}$

ACT 3, Scene i. Following the night scenes of Act II, Act III becomes a fully grotesque affair. The bawd's saraband in minor and funeral march forms the introduction. In the middle, we hear the women grumble and the hanged men moan. When the curtain rises, we see the familiar room, draped in common black. Elicia and Areúsa are crying, not so much for pain at the loss of Celestina as for the loss of the men, their hanged lovers. Virginius enters, in ridiculous mourning attire, attempting to cheer them up. He says that the city's mourning is genuine and that even the courts are showing compassion and at many houses black banners are displayed. ${ }^{37}$ When he starts to be annoyingly petulant, the unnerved prostitutes ask him to leave. Centurio arrives, changed, secure finally in his triumph. He describes, deliciously, the details of the hanging of Sempronio and Pármeno, stating that there now remain no obstacles to his demands. Until now, the girls had disdained this tubby and vulgar pimp. Now, counting his money (...) Elicia and Areúsa become enraged and they throw his money in his face. Calisto is the author of their misfortune and were Centurio to go off and kill Calisto, they might then do whatever he wishes of them. Centurio leaves, all excited. They are crying, covering their faced with their hands. A door opens silently above them. Flores, covered all but her head in a greatcoat, tiptoes out of the house. ${ }^{38}$

Scene ii. Hippolytus' house. A small, spare room, showing great neglect, a reflection of its occupant. We hear Hippolytus' aria as he suddenly understands all. With Celestina's death the magic has ended for everyone, all are left with only the crudest reality. Hippolytus, too, knows he has sacrificed his hopes for Melibea in pursuit of a fantasy. Flores enters. By the light of day, we see clearly for the first time the caricature of Melibea, painted and sinister. She desires him again, but he feels only revulsion as though brought to gaze upon a horrific apparition. He rejects Flores, and she curses Celestina, who took away her life to create the illu-

36.- Gregor has made quite an Apocalypse of Celestina's assassination. In the original Celestina, after the bawd is murdered, witnessed only by Elicia, the servants escape through a second-story window and are apprehended by the gendarmes patrolling nearby. They are executed in a public square at dawn, off stage. This occurs before the first sexual coupling of the lovers, Calisto and Melibea, unlike here.

37.- Recall that this mourning-draped city was one of the «exaggerations» of the sketch objected to by Strauss [see his letter to Gregor of July 27, 1936]. This sentence is crossed out on the typescript [by which of the two men?], but supplied here in square brackets.

38.- In the original it is not Centurio who relates to Elicia and Areúsa the executions of Pármeno and Sempronio, but Sosia tells of it to Calisto. In the opera these actions are differently motivated, although, as in Celestina, it is the prostitutes who put Centurio up to arranging the death of Calisto. 
sion of a stranger. Upon hearing these words, suddenly all becomes clear to Hippolytus: Calisto is the true author of his unhappy state. He will murder him. He arms himself and departs in haste. ${ }^{39}$

Scene iii. Pleberio's house. The parents, as earlier [there is a lacuna here] ... murdered by a treacherous hand, with the assassins having been justly punished. In the end, favor is with the wealthy but foolish Calisto, but the mother continues to prefer her ideal, Hippolytus. They approach Melibea's room with soothing conversation, from which room noises are discernable.

Scene iv. Melibea's room. Lucretia, who is readying her mistress for the tryst with Calisto, tells her about the death of Celestina. Melibea shudders to realize that she is the cause, albeit an innocent one, of all this. Lucretia wails, for she has realized no profit. Calisto appears, the only one unaffected by the commotion, preoccupied only in pursuing his amorous designs. With a pure, sincere voice, Melibea implores him to put an end to all artifice and to flee with her. Warning signs have increased at every turn: swordplay has been heard outside the house in the dark, then the death of the witch, followed by that of the servants [...]. Calisto is vacillating, but he manages to convince Melibea to enjoy just being together. The love duet is, then, tinged with the strains of Celestina's saraband in minor key. It is as if no one can free himself from her ghostly presence.

Scene v. The garden. Tristan and Sosia stand watch. They, too, speak of the death of the other two servants. They cannot explain how they have come to play a role in this affair and are, simply, afraid. Would that their advice had been taken earlier and all gone on a drinking spree, or to a bullfight. A gentleman approaches on horseback. They take to their heels instantly. Virginius, wearing a mask, explains that his valor would soon be confirmed, when he kills the cause of all his misfortunes, Calisto. $\mathrm{He}$ brandishes his sword in the air. Another man enters from the opposite side. It is Hippolytus. Each mistakes the other for Calisto. Hippolytus instills fear at once in Virginius. Yet there is a third man now, the fat Centurio. A wild melee follows. The three, fighting, skirt the house, each with the identical shout: "O Celestina.» It is as though the witch still held them all in her thrall. Exhausted, Centurio falls backward: he has lost his sword. He is grotesque in his despair at not killing Calisto. Then, in the darkness, he bumps into the rope ladder and has a brilliant idea: he has not promised to kill Calisto with his sword. He carefully severs several of the ropes that make the ladder's steps. ${ }^{40}$

39.- None of this scene has its source in the original Celestina.

40.- In Celestina, Centurio is only indirectly involved in Calisto's fall, as he - a cowardhires a confederate, Traso the Lame, to take his place. Calisto falls while rushing to the aid of his servants, supposedly under attack as they stand guard outside the garden. The novelty here is in making Centurio directly responsible. However, ever the coward, he resorts to underhand means to bring about the result he desires. 
Scene vi. Balcony scene. The two lovers bid each other farewell. Below, Hippolytus waits with his dagger unsheathed and Centurio smirks from his hiding place. Melibea implores Calisto, beguilingly and expressively, to free her of Celestina's ghost. ${ }^{41}$ Calisto, confused, descends the rope ladder's steps, singing his theme ballad, until... he falls!

Scene vii. The garden, with a great hullabaloo. Calisto's cries out. A few of Pleberio's servants carry him off. Melibea has heard the cry and rushes from the house in great agitation. She begs for help, calling on Calisto's servants, who only then appear, all sleepy-eyed and slow-witted. According to them, Calisto has only a broken leg, but they, thinking to put an end to this disagreeable affair, prefer to report that he has died. They communicate this (false) information to Melibea in a horrific duet. She, sighing, faints. Tristan and Sosia flee the scene. Now everything comes to life, servants, flambeaux, Melibea's parents. Slowly Melibea regains consciousness. The parents are made aware with great pathos that Melibea is guilty of their loss of honor. Hippolytus emerges from the darkness and blames Melibea for his own destroyed hopes. Suddenly, all the players but Calisto appear in the garden, as if by magic, each blaming Melibea for all that has happened. Areúsa and Elicia bewail the loss of their lovers, Flores curses Melibea, Virginius bemoans his loss of virility, and Centurio blames her for his failure to kill Calisto. It is a chorus of vengeance of the cruel Furies against a totally innocent Melibea.

Melibea struggles to her feet, serious. She knew that Celestina had bewitched her first of all: she never loved Calisto but was, instead, forced to love him. All — men and women — had to give way, against their will, in the wake of the spells of the witch, whose ghostly presence then continued to haunt this house. All —as if the witch were still present-continue to remain in her thrall. And though she, Melibea, is the youngest of all, she was the only one with suffiicent force to free herself of the old bawd and to finally overcome her spells. She unsheaths a dagger and stabs herself. ${ }^{42}$

The cruel saraband is heard once again in the air, this time disfigured and broken. The final music heard is Melibea's theme, soft and quietly fading to a close. THE END.

41.- In the Spanish original, Melibea never gives a thought to Celestina. She is concerned only for Calisto's safety as he rushes to the aid of his servants. This "ghost» of Celestina that affects all the operatic characters is one of the ways Strauss and his librettist chose to make Celestina the very essence of the tragedy, even after her assassination.

42.- The new plot line calls for a new ending. Whereas Melibea, after Calisto's fall from the ladder in the original, leaps from a tower to «imitate» the fall of her beloved and to be with him even in death, the opera has their affair reduced to illusion, an act of witchcraft, and her suicide with the dagger in the opera-to-be responds to entirely different motivations. 


\section{Appendix II.}

\section{Twentieth-Century Celestina operas}

[N.B. As the following demonstrates, there have been Celestina operas composed, and with librettos in different languages, but only infrequently performed, if at all. Owing to the music extant, we have added information about three Celestina ballets that have been created and performed but, however, to the best of our knowledge, have not been danced subsequently.]

1902 Composed from June-August, by Felipe Pedrell (1841-1922). Amor. La Celestina. Tragicomedia lírica de Calisto y Melibea. Opera in four acts and twenty-one scenes. Complete musical score and Castilian libretto by Pedrell. French libretto by Henri Curzon; Italian libretto by Angelo Binotti. A reduction for voice and piano was published in Barcelona by Casa Dotesio in 1903. This was reprinted on the occasion of its $100^{\text {th }}$ anniversary [Alicante: Biblioteca Virtual Joan Lluis Vives, 2003]. Pedrell's opera has never been staged in full.

Performances: A fragment was performed in Bordeaux in 1910, with the backing of the hispanist, Henri Collet. A selection was played by the Catalan cellist, Pablo Casals, during the homage to Pedrell on his $80^{\text {th }}$ birthday, October 22, 1922. Parts of the score were performed at a posthumous ceremony in 1922 honoring Pedrell by, again, Pablo Casals. Manuel de Falla, Pedrell's student, wrote in his Argentine exile Suites Homenajes: its final movement, "Pedrelliana» contains music from the opera and was performed on November 18, 1939 in Buenos Aires. A musical piece based on Pedrell and with the Italian lyrics supplied by Angelo Binotti, adapted by Flavio Testi, was performed at the Teatro Maggio Fiorentino in Florence in 1963. A sampling of the opera was performed at Madrid's Círculo de Bellas Artes in autumn of 1984 (voice and piano), as one of the events surrounding the production of an adaptation by Ángel Facio and his Teatro del Aire.

An early history of Pedrell's opera appears in J. T. Snow's "La Celestina of Felipe Pedrell,» Celestinesca 3.1 (May 1979), 19-32.

More about the Italian performance is to be found in Arcadio de Larrea, «Sobre La Celestina (ópera de Pedrell),» Arbor 56, no. 213 (1963), 135-136.

1961 Flavio Testi (1923-), composer. La Celestina. Opera in tre atti dalla tragicommedia omonima di Fernando de Rojas. Libretto by Renato Prinzhofer. For voice and piano. Milan: Ricordi, 1961. 387 pp. Its 
performance debut took place in Florence's Teatro della Pergola on May 28, 1963.

1962 Federico Romero. Tragicomedia musical, en tres actos, basada en la clásica obra de Fernando de Rojas. This is a verse adaptation, prepared by the early 1960's with the hopes that Oscar Esplá would compose the music for it. See also, below, 1973-1974.

The text/libretto is published, along with another previously unedited work, "Rebelión en el retablo,» Madrid: Preyson, 1983. Additional information on this musical tragicomedy is available in the Prologue by F. C. Sainz de Robles.

1966-1968 Ángel Arteaga composed an opera based on Celestina. The only reference to this we have seen appears in José Luis García del Busto "Recopilación musical: Celestinas,» in Tres mitos españoles (Celestina, Don Quijote, Don Juan), Madrid: Sociedad de Conmemoraciones Culturales, 2004, p. 110.

1970s Karl-Heinz Füssl (1924-1992) composed a two act opera with lyrics by Herbert Lederer. It was performed in Karlsruhe's Badisches Staatstheater in 1976. It was revised in 1987.

Oscar Esplá (1886-1976) supposedly composed a "Calixto y Melibea» based on the libretto by Federico Romero. This information comes from García del Busto, p. 100 (see 1973-1974 entry for 1966-168, above), but contradicts a statement made by M. A. Lozano Marco in Sociedad, arte y cultura en la obra de Oscar Esplá (Madrid: INAEM, 1996) to the effect that Esplá undertook several projects with a literary inspiration and a few of these never came to fruition, including an opera based on Celestina (p. 90).

1979 Jerome Rosen composer. Calisto \& Melibea. Libretto by Edwin Honig. Opera in three acts and sixteen scenes. It had its world premiere on May 31, 1979, with Jan Popper conducting, in Davis, California.

Performance review: Reed Anderson in Celestinesca 3.2 (1979): 27-30.

Honig's libretto was published in Providence Rhode Island, by Hellcoal Press in 1972. It is reviewed separately by J. T. Snow in Celestinesca 3.2 (1979): 32-40.

1982-1986 Maurice Ohana (1892-1987), composer of La Celestina. Tragicomedia lírica basada en Fernando de Rojas. Commissioned by Radio 
France. French libretto by Odile Marcel and Maurice Ohana. An opera of two acts, comprised of eleven tableaux, plus a prologue and an epilogue. For thirteen solo voices. It had its world Premiere at the Palais Garnier, Paris, June 13, 1988. Staged by Jorge Lavelli, with Arturo Tamayo conducting. The American mezzo soprano, Katherine Ciesinski, sang the title role.

An extensive review by Adrienne Mandel, appears in "Celestina's Seductive Power in France. An Operatic Debut,» in Fernando de Rojas and 'Celestina': Approaching the Fifth Centenary, ed. I. A. Corfis and J. T. Snow (Madison WI: Hispanic Seminary of Medieval Studies, 1993), pp. 283-293. Mandel's piece contains notices of many other reviews.

1965-1986 Joaquín Nin Culmell (1908-2004), composer and librettist. For eight solo voices, choir and orquestra. La Celestina. Published Paris, 1995 [?]. ${ }^{43}$ In 1999 or 2000, Nin Culmell was in Madrid seeking to have his Celestina opera recorded. Alexis Soriano helped him produce a version for piano but no support was made available for an orchestral version. A world premier of this opera was scheduled for Barcelona's Liceu when a fire cancelled all programming. Now rebuilt, the Liceu has made no announcement about a future performance of this Celestina. Nin Culmell, younger brother to Anais Nin, was a desdendant of the Juan Antonio Nin y Serra, with whom Felipe Pedrell had studied. He died in Oakland, California in 2004, near to the Berkeley campus of the University of California where he had taught music composition for several decades.

\section{Ballets inspired by «Celestina»}

1968 Created by Alberto Cárdenas especially for Susana \& Jose, who performed it in Madrid in 1968.

1990 «La Celestina.» Ballet created, choreographed and danced by Paco Romero (as Calisto) and his troupe, Ballet España. Music by Manolo Sanlúcar. Seen in Madrid, September 12-16, 1990.

43.- Nin Culmell wrote JTSnow a letter about 1995 (possibly after), inviting him to be in touch with his French publisher where he might obtain a copy of his Celestina opera. Snow, unfortunately, did not follow up on this invitation and now finds he has misplaced Nin Culmell's letter. We have not seen this Opera in print, nor have we been successful in locating it on the Internet. 
Strauss, Zweig, Gregor \& the Celestina

Celestinesca 31, $2007 \quad$ 163

Performance Review: Mercedes Rico, El País, 14 September 1990.

1998 Ballet of aLa Celestina,» choreographed by Ramon OIler to music [in seventeen scenes] composed by Carmelo Bernaola [in 1996], this ballet was danced by Aida Gómez' Ballet Nacional de España and directed by Adolfo Marsillach. Marsillach had previously dirested a stage performance of Celestina in 1988 for the Compañía Nacional de Teatro Clásico (with occasional music by Bernaola), and it was his "Sinopsis para un ballets [of Celestina] that led to this new collaboration a decade later. It had its world premiere at Madrid's Teatro Real on June 24, 1998, music conducted by Jose Ramón Encinar.

Performance review: J. T. Snow, Celestinesca 22.2 (Otoño 1998): 85-88.

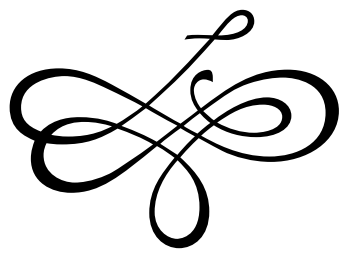




\section{Snow, Joseph T. y Gimber, Arno, «Richard Strauss, Stefan Zweig, Joseph Gregor and the Story of the Celestina Opera that Almost was, with a Bibliographical Appendix of Celestina Operas in the Twentieth Century", Celestinesca 31 (2007), pp. 131-162.}

\section{RESUMEN}

Stefan Zweig, el conocido novelista austríaco y judío, colaboró con Richard Strauss en su Die Schweigsame Frau (La mujer silenciosa) en 1935 y, después, le sugirió al compositor una ópera basada en Celestina. El proyecto interesó a Strauss y quiso que Zweig fuese su colaborador, pero Zweig, en la Alemania de Hitler, temía más colaboraciones con Strauss y le propuso que trabajara con Josef Gregor, afamado historiador de teatro mundial. La historia completa de esta ópera que nunca llegó a componerse aparece aquí completa, respaldada por las cartas que escribieron los tres. Incluimos en dos apéndices una versión en inglés de la ópera que diseñó Gregor para Strauss además de una lista comentada de las óperas basadas en Celestina en el siglo veinte.

PALABRAS ClaVE: Die Schweigsame Frau, Stefan Zweig, Richard Strauss, Josef Gregor

\section{ABSTRACT}

Stefan Zweig, the famed Austrian novelist and Jew, colaborated as librettist in Richard Strauss' Die Schweigsame Frau (The Silent Woman) in 1935 and afterward suggested to the composer an opera based on Celestina. Strauss was interested and desired that Zweig work on it with him, but in Hitler's Germany, Zweig was fearful of further collaborations and suggested that he work with Josef Gregor, a theater historian. The whole story of this unrealized opera project - almost never mentioned in Strauss biograhies - is retold here from the letters that passed between the three. We include in two appendices an English version of the tenpage sketch produced for Strauss by Gregor, and a review of operas based on Celestina in the twentieth century.

KEY WORDS: Die Schweigsame Frau, Stefan Zweig, Richard Strauss, Josef Gregor 